Kumawula, Vol. 3, No.1, April 2020, Hal 29 - 47

DOI:http://10.24198/kumawula.31i1.24860

ISSN 2620-844X (online)

Tersedia online di http://jurnal.unpad.ac.id/kumawula/issue/view

\title{
PERENCANAAN PARTISIPATIF DALAM PROGRAM CITARUM HARUM DI DESA KUTAMANDIRI KECAMATAN TANJUNGSARI KABUPATEN SUMEDANG
}

\author{
Ratnia Solihah \\ Departemen Ilmu Politik, Fakultas Ilmu Sosial dan Ilmu Politik, Universitas Padjadjaran \\ ratnia@unpad.ac.id
}

\begin{abstract}
ABSTRAK
Fokus tulisan ini tentang perencanaan partisipatif dalam Program Citarum Harum sebagai upaya menindaklanjuti hasil survey kondisi fisik dan sosial, pemetaan masalah dan potensi Desa Kutamandiri Kecamatan Tanjungsari Kabupaten Sumedang terkait bidang penanganan lahan kritis dan pengendalian erosi, konservasi air, sanitasi lingkungan, pengelolaan sampah dan limbah pertanian, dan mitigasi bencana. Metode dalam tulisan ini adalah metode kualitatif, dengan teknik pengambilan data berdasarkan studi literatur dan studi lapangan. Studi lapangan dilakukan melalui survey, Participatory Actions Research (PAR) dan memfasilitasi perencanaan partisipatif program Citarum Harum melalui FGD. Perencanaan partisipatif dalam Program Citarum Harum melalui FGD dilakukan dengan kegiatan pemaparan hasil survey kondisi fisik dan sosial, pemetaan masalah dan potensi Desa Kutamandiri, sosialisasi pentingnya perencanaan partisipatif berbasis "active citizens" melalui FGD, diskusi kelompok kecil tentang masalah, potensi dan solusi dalam program Citarum Harum, serta pemaparan mengenai ide, gagasan, masukan dan solusi untuk mengatasi permasalahan terkait bidang penanganan lahan kritis dan pengendalian erosi, konservasi air, sanitasi lingkungan, pengelolaan sampah dan limbah pertanian, dan mitigasi bencana. Secara keseluruhan kegiatan perencanaan partisipatif melalui FGD dapat dilakukan dengan baik, walaupun tidak seluruh warga dapat hadir dalam FGD tersebut. Hasil FGD sebaiknya ditindaklanjuti dalam berbagai kegiatan yang riil dalam lingkup jangka pendek, jangka menengah dan jangka panjang.
\end{abstract}

Kata Kunci: perencanaan, partisipatif, program, citarum harum, desa

\begin{abstract}
The focus of this paper is on participatory planning in the Citarum Harum Program as an effort to follow up on the results of a survey of physical and social conditions, mapping of problems and potentials of Kutamandiri Village, Tanjungsari District, Sumedang Regency related to the fields of handling critical land and erosion control, water conservation, environmental sanitation, waste management and agricultural waste, and disaster mitigation. The method in this paper is a qualitative method, with data collection techniques based on literature studies and field studies. Field studies were carried out through surveys, Participatory Actions Research (PAR) and facilitating participatory planning of the Citarum Harum program through FGDs. Participatory planning in the Citarum Harum Program through FGD is carried out with the presentation of the results of surveys of physical and social conditions, mapping of problems and potentials of Kutamandiri Village, the socialization of the importance of participatory planning based on "active citizens" through FGD, small group discussions about problems, potentials and solutions in the Citarum Harum Program, as well as presentation of ideas, ideas, input and solutions to overcome problems related to the fields of handling critical land and erosion control, water conservation, environmental sanitation, management of
\end{abstract}


agricultural waste and waste, and disaster mitigation. Overall participatory planning activities through the FGD can be carried out well, although not all residents can attend the FGD. The results of the FGD should be followed up in a variety of real activities in the scope of the short term, medium term and long term.

Keywords: planning, participatory, program, citarum harum, village

\section{PENDAHULUAN}

Program “Kembalikan Citarum Harum” merupakan program yang dicanangkan pemerintah untuk mengatasi permasalahan yang ada di DAS Citarum. Meskipun sudah mencanangkan program "Kembalikan Citarum Harum”, pada kenyataannya langkah yang ditempuh tidaklah mudah mengingat kompleksitas permasalahan yang dihadapi di lapangan. Masalah semakin parahnya kerusakan lingkungan, tidak tertibnya perilaku masyarakat dalam menerapkan fungsi sungai, adanya mismanajemen dalam pengelolaan sungai serta masih rendahnya kepedulian berbagai pihak dalam mengatasi masalah DAS Citarum menjadi hambatan untuk mewujudkan program “Kembalikan Citarum Harum”. Peran Perguruan Tinggi sangat dibutuhkan untuk mencapai keberhasilan program dalam upayanya merevitalisasi DAS Citarum (Proposal KKN Citarum Harum 2019).

Untuk mendukung program “kembalikan Citarum Harum” tersebut, UNPAD menjalankan Program Kuliah Kerja Nyata (KKN) Tematik Citarum Harum terintegrasi dengan kegiatan Pengadian Pada Masyarakat Dosen, yang diselenggarakan berdasarkan konteks wilayah dan justifikasi isu di lapangan serta upaya pemecahan masalah terkait DAS Citarum.

Salah satu desa yang menjadi obyek lokasi KKN Citarum Harum adalah Desa Kutamandiri Kecamatan Tanjungsari Kabupaten Sumedang, yang menjadi salah satu desa yang dialiri DAS Citarik yang bermuara ke sungai Citarum. Berkaitan dengan program citarum tersebut, pada tahun 2001 dimulai program DAS Citarik yang diselenggarakan oleh pemerintah Kabupaten Sumedang yang berjalan selama 1 tahun.

Berdasarkan hasil survey KKN yang dilakukan oleh Tim mahasiswa KKN Citarum Harum di Desa Kutamandiri (Borang Isian KKN UNPAD Desa Kutamandiri), ditemukan halhal yang baik yang sudah ada dalam kegiatan Masyarakat desa terkait "program kembalikan Citarum Harum”, yaitu:

a. Sudah terbentuknya beberapa kelembagaan di desa yang menangani program sanitasi lingkungan dan pengelolan sampah (PKK melalui Pokja IV), Penanganan lahan kritis (Gapoktan), Mitigasi bencana (Babinsa dan Linmas Desa Kutamandiri). 
b. Adanya rintisan program citarum di desa yaitu program ecovillage di desa kutamandiri dengan cara diadakannnya sosialisasi dan pelatihan bank sampah.

c. Dilaksanakannya program pembersihan selokan yang periodik yang di cetuskan oleh kelompok masyarakat (gapoktan) dibantu dengan masyarakat sekitar.

d. Adanya program saluran pembuangan air limbah terpusat (SPAL-DT),

e. Adanya program sanitasi berbasis masyarakat islamic development bank (SANIMAS IsDB) serta kelompok swadaya masyarakat (KSM. CITRA MANDIRI).

f. Pada tahun 2019 adanya bantuan sosial yaitu perbaikan rumah tidak layak huni (RUTILAHU) dengan 60 penerima bantuan dengan biaya masing-masing penerima sebesar RP. 17.500.000,00.

Di sisi lain , hal-hal yang masih menjadi permasalahan terkait dengan Program Citarum Harum (Borang Isian KKN UNPAD Desa Kutamandiri), antara lain:

a. Wilayah Desa Kutamandiri terdiri dari lahan pemukiman, pertanian, dan epeternakan. Desa ini memiliki beberapa titik lahan kritis yang cukup luas serta memiliki 9 titik mata air berupa sumur umum. Beberapa warga memanfaatkan sumur umum sebagai sumber air untuk melakukan aktivitas sehari-hari namun sumur umum ini tidak dilengkapi dengan pompa dan saluran pipa ke rumah warga sehingga warga sulit untuk mengakses air. Selain itu, beberapa sumur juga mengering ketika musim kemarau panjang datang.

b. Adanya titik lahan kritis yang cukup luas di beberapa wilayah menjadi dugaan berkurangnya muka air tanah akibat pengelolaan lahan yang kurang baik sehingga membuat struktur tanah bagian atas tidak dapat meresap air dengan baik. Beberapa kondisi air sumur umum di desa ketika kemarau mengalami pengurangan debit air atau dapat dikatakan air yang keluar hanya sedikit.

c. Sebagian besar warga hanya berfokus pada pemanfaatan air dan lahan namun belum memiliki kesadaran akan pentingnya ketersediaanya di masa yang akan datang.

d. Kurangnya perhatian terhadap masalah sampah, terutama tempat pembuangan di di rumah-rumah penduduk, di temapat tempat umum, Tempat Pembuangan Sampah Sementara (TPS) dan Tempat Pembuangan akhir (TPA).

e. Pencegahan yang bertujuan untuk menyelamatkan lingkungan desa masih sangat kurang, karena tidak adanya program dan visi penyelamatan lingkungan yang konkrit.

f. Tidak memiliki kelompok masyarakat yang didampingi secara berkelanjutan. Hal ini menyebabkan masyarakat hanya bergerak ketika bencana sudah terjadi. 
Berdasarkan profil, masalah dan potensi tersebut, maka perlu dilakukannya perencanaan partisipatif dalam Program Citarum Harum yang berbasis “active citizens” melalui FGD untuk mengatasi permasalahan dengan mempertimbangkan kondisi fisik dan sosial serta potensi Desa Kutamandiri.

Perencanaan partisipatif yang melibatkan masyarakat akan mempunyai dampak yang sangat penting dalam pembangunan, yaitu: terhindar dari peluang terjadinya manipulasi, memberikan nilai tambah pada legitimasi rumusan perencanaan, serta meningkatkan kesadaran dan ketrampilan politik masyarakat (Abe, 2005: 47). Oleh karenanya, pemahaman masyarakat terhadap perencanaan partisipatif merupakan sesuatu yang sangat diperlukan dalam upaya pelaksanaan partisipasi perencanaan pembangunan partisipatif. Pemahaman terhadap perencanaan partisipatif akan menimbulkan kesadaran masyarakat terhadap pentingnya partisipatif masyarakat (Laily, 2015:188).

Berdasarkan hal tersebut, manfaat yang diharapkan dari perencanaan partisipatif dalam Program Citarum Harum melalui FGD di Desa Kutamandiri ini adalah:

a. Dengan perencanaan partisipatif dalam Program Citarum Harum melalui FGD yang melibatkan warga desa dan lembaga-lembaga pemerintahan dan kemasyarakatan yang ada di desa, dapat menciptakan ide, gagasan dan pemikiran tentang kegiatan yang dapat dilakukan terkait kondisi, permasalahan dan potensi yang ada di desa, serta menumbuhkan rasa kebersamaan, gotong royong, kepedulian dan tanggung jawab dalam menangani permasalahan-permasalahan yang erat kaitannya dengan program tersebut yang telah mereka usulkan dan rumuskan bersama-sama.

b. Dengan perencanaan partisipatif dalam Program Citarum Harum melalui FGD yang melibatkan warga desa dan lembaga-lembaga pemerintahan dan kemasyarakatan yang ada di desa, dapat mengantisipasi, mengatasi dan memberikan solusi bagi permasalahan dalam Program Ciatrum Harum di wilayah Desa Kutamandiri, khususnya di bidang penanganan lahan kritis dan pengendalian erosi, konservasi air, sanitasi lingkungan, pengelolaan sampah dan limbah pertanian, dan mitigasi bencana.

\section{METODE}

Dalam tulisan ini, digunakan metode kualitatif, dimana dalam memperoleh data digunakan studi literatur terkait pemberdayaan masyarakat melalui kewirausahaan sosial dan digunakan studi lapangan. Studi lapangan dilakukan melalui survey kondisi fisik dan sosial serta pemetaan masalah dan potensi Desa Kutamandiri, Participatory Actions Research (PAR) 
dengan menekankan upaya untuk membangun kolaborasi antara Mahasiswa, Dosen dan berbagai elemen masyarakat sebagai upaya mengatasi permasalahan di DAS Citarum, dan memfasilitasi perencanaan partisipatif program Citarum Harum melalui FGD yang melibatkan Dosen, Tim mahasiswa KKN, warga desa, serta lembaga-lembaga pemerintahan dan lembaga-lembaga kemasyarakatan di Desa Kutamandiri.

Tahapan-tahapan kegiatan perencanaan partisipatif dalam Program Citarum Harum melalui FGD di Desa Kutamandiri, dilakukan melalui beberapa kegiatan berikut:

1. Melakukan survey bersama masyarakat terkait empat topik yaitu Sanitasi Lingkungan, Pengelolaan sampah dan Limbah Pertanian, Mitigasi Bencana, serta Konservasi Air dan lahan kritis. Survey dilakukan bersama dengan Kepala Dusun (Kadus) dari tiap dusun. Metode yang digunakan adalah mewawancarai dan mendatangi informan secara langsung. Berhubung di Desa Kutamandiri ada empat dusun yang letaknya memanjang mengikuti jalan utama, jadi mahasiswa KKN dibagi menjadi empat kelompok. Setiap kelompoknya terdiri dari mahasiswa yang masing-masing memiliki topik berbeda yang harus digali selama survey.

2. Melakukan Survey bersama Gapoktan terkait lima bidang Program Citarum Harum yaitu Penanganan Lahan kritis dan Pengendalian Erosi, Konservasi Air dan Tanah, Sanitasi Lingkungan, Pengelolaan sampah dan Limbah Pertanian, serta Mitigasi Bencana. Survey dilakukan bersama dengan Kepala Dusun (Kadus) dari tiap dusun. Metode yang digunakan adalah mewawancarai dan berdiskusi secara langsung di tempat survey bersama Gapoktan

3. Susur Sungai

Kelompok KKN Desa Kutamandiri melakukan susur sungai bersama kadus dan aparat daerah, dengan metode survey secara langsung menyusuri aliran sungai, dan melakukan wawancara kepada kadus mengenai permasalahan sungai di desa Kutamandiri

4. Kegiatan perencanaan partisipatif tentang Sanitasi Lingkungan serta Pengelolaan sampah dan Limbah Pertanian.

Kegiatan ini dilaksanakan pada hari Senin, 4 November 2019. Metode yang digunakan adalah FGD (Focus Group Discussion). Metode ini digunakan agar peran aktif masyarakat dapat terlaksana sehingga masyarakat dapat mencurahkan ide dan gagasan yang dimiliki untuk Program Citarum Harum. Pada pelaksanaan FGD, masyarakat, Ketua RW, Ketua RT dan karang taruna dilibatkan bersama Tokoh Masyarakat yang memiliki wawasan mengenai Sanitasi Lingkungan dan Pengelolaan sampah dan Limbah Pertanian. Pihakpihak yang dilibatkan dalam kegiatan ini adalah Bidan Desa, Tim PKK, Penyuluh 
Pertanian (PPL),Ketua BPD, Ketua LPMD, Kepala Dusun, untuk membimbing dan mengarahkan terkait masalah, penyebab, dan solusi mengenai topik yang bersangkutan. Lalu ide dan gagasan dituliskan dalam kertas plano yang telah disediakan. Selanjutnya tiap kelompok akan memaparkan ide dan gagasannya di depan kelompok lain. Hal ini dilakukan agar ide-ide lain dapat tertampung.

5. Kegiatan perencanaan partisipatif tentang penanganan lahan kritis dan penegndalian erosi, konseravsi air dan tanah, serta mitigasi bencana.

Kegiatan ini dilaksanakan pada hari Selasa, 5 November 2019. Metode yang digunakan adalah FGD (Focus Group Discussion). Metode ini digunakan agar peran aktif masyarakat dapat terlaksana sehingga masyarakat dapat mencurahkan ide dan gagasan yang dimiliki untuk program Citarum Harum. Pada pelaksanaan FGD, masyarakat, Ketua RW, Ketua RT dan karang taruna dilibatkan bersama Tokoh Masyarakat yang memiliki wawasan mengenai penanganan lahan kritis dan pengendalian erosi, konservasi air dan tanah, serta mitigasi bencana. Pihak-pihak yang dilibatkan dalam kegiatan ini adalah Ketua Gapoktan, Ketua LPMD, Babinsa/Babinkamtibmas, Ketua BPD, Kepala Dusun, untuk membimbing dan mengarahkan terkait masalah, penyebab, dan solusi mengenai topik yang bersangkutan. Lalu ide dan gagasan dituliskan dalam kertas plano yang telah disediakan. Selanjutnya tiap kelompok akan memaparkan ide dan gagasannya di depan kelompok lain. Hal ini dilakukan agar ide-ide lain dapat tertampung.

\section{HASIL DAN PEMBAHASAN}

Program adalah unsur pertama yang harus ada demi terciptanya suatu kegiatan (Putri dkk, 2014: 3). Di dalam program dibuat beberapa aspek, disebutkan bahwa di dalam setiap program dijelaskan mengenai: (1) Tujuan kegiatan yang akan dicapai; (2) Kegiatan yang diambil dalam mencapai tujuan; (3) Aturan yang harus dipegang dan prosedur yang harus dilalui; (4) Perkiraan anggaran yang dibutuhkan; dan (5) Strategi pelaksanaan.

Menurut Jones (1996: 294), melalui program maka segala bentuk rencana akan lebih terorganisir dan lebih mudah untuk dioperasionalkan. Hal ini sesuai dengan pengertian program berikut: "A programme is collection of interrelated project designed to harmonize and integrated various action an activities for achieving averral policy abjectives" (suatu program adalah kumpulan proyek-proyek yang berhubungan telah dirancang untuk melaksanakan kegiatan-kegiatan yang harmonis dan terintegrasi untuk mencapai sasaran kebijaksanaan tersebut secara keseluruhan). 
Program terbaik di dunia adalah program yang didasarkan pada model teoritis yang jelas, yakni: sebelum menentukan masalah sosial yang ingin diatasi dan memulai melakukan intervensi, maka sebelumnya harus ada pemikiran yang serius terhadap bagaimana dan mengapa masalah itu terjadi dan apa yang menjadi solusi terbaik (Jones, 1996: 295).

Dengan demikian, program adalah rangkaian kegiatan-kegiatan atau seperangkat tindakan untuk mencapai tujuan. Suatu program dalam mencapai tujuan akan tersusun dengan melakukan perencanaan program. Perencanaan program yang memerlukan peran serta atau partisipasi masyarakat dalam proses penyusunan, perumusan dan implementasinya, maka muncullah perencanaan partisipatif.

Partisipasi masyarakat dapat didefinisikan sebagai keterlibatan dan pelibatan anggota masyarakat dalam pembangunan, meliputi kegiatan dalam perencanaan dan pelaksanaan (implementasi) program pembangunan (Adisasmita, 2006: 38). Partisipasi masyarakat dalam perencanaan program pembangunan merupakan bentuk perencanaan partisipatif. Perencanaan partisipatif mulai dikenal secara luas sejak munculnya metode partisipatif yang biasa disebut Participatory Rural Appraisal. Metode ini menekankan adanya peran serta aktif dari masyarakat dalam merencanakan pembangunan (penyelesaian masalah) mulai dari pengenalan wilayah, pengidentifkasian masalah sampai pada penentuan skala prioritas (Sili, 2014: 3).

Perencanaan partisipatif saat ini mulai merambah ke tingkat makro atau lebih pada pengembangan kebijakan, biasanya kegiatan ini lebih banyak dilakukan oleh Lembaga Non Pemerintah (NGO’s). Selain itu perencanaan partisipatif banyak dilakukan di tingkat mikro seperti pada tingkat masyarakat maupun di tingkat individu.

Secara garis besar perencanaan partisipatif mengandung makna adanya keikutsertaan masyarakat dalam proses perencanaan pembangunan, mulai dari melakukan analisis masalah mereka, memikirkan bagaimana cara mengatasinya, mendapatkan rasa percaya diri untuk mengatasi masalah, mengambil keputusan sendiri tentang alternatif pemecahan masalah apa yang ingin mereka atasi.

Tiga alasan utama mengapa perencanaan partisipatif dibutuhkan, yaitu (Conyers, 1991, 154-155).

1. Alasan pertama partisipasi masyarakat merupakan suatu alat guna memperoleh informasi mengenai kondisi, kebutuhan dan sikap masyarakat setempat yang tanpa kehadirannya program pembangunan serta proyek-proyek akan gagal. 
2. Alasan kedua adalah bahwa masyarakat akan lebih mempercayai kegiatan atau proram pembangunan jika merasa dilibatkan dalam proses persiapan dan perencanaannya, karena mereka akan lebih mengetahui seluk beluk program tersebut dan akan mempunyai rasa memiliki terhadap program tersebut.

3. Alasan ketiga adalah karena timbul anggapan bahwa merupakan suatu hak demokrasi bila masyarakat dilibatkan dalam proses pembangunan.

Kegiatan perencanaan partisipatif dalam Program Citarum Harum melalui Focus Group Discussion melibatkan warga desa dan lembaga-lembaga pemerintahan dan lembaga kemasyarakatan yang ada di Desa Kutamandiri. Kegiatan FGD tersebut disampaikan penjelasan tentang pentingnya perencanaan partisipatif berbasis “active citizens" dalam Program Citarum Harum oleh Dosen sebagai Narasumber, pemaparan hasil survey dan hasil pemetaan masalah, permasalahan yang dirasakan warga secara langsung; serta dilakukannya diskusi dan usulan berupa solusi untuk mengatasi permasalahan di bidang penanganan lahan kritis, bidang konservasi air, bidang sanitasi lingkungan, bidang pengelolaan sampah, dan bidang mitigasi bencana, yang dihasilkan diantaranya yaitu:

\section{Bidang Penanganan Lahan Kritis}

Menurut Poerwowidodo (1990), lahan kritis adalah suatu keadaan lahan yang terbuka atau tertutupi semak belukar, sebagai akibat dari solum tanah yang tipis dengan batuan bermunculan dipermukaan tanah akibat tererosi berat dan produktivitasnya rendah.

Dalam kegiatan perencanaan partisipatif dalam Program Citarum Harum melalui FGD di Desa Kutamandiri dipaparkan hasil survey dan pemetaan masalah terkait penanganan lahan kritis sebagai berikut:

a. Pada dusun 1 didominasi oleh kemeringan lereng yang curam tetapi warga dapat memanfaatkan dengan baik karena kemiringan lerek tersebut dibuat terasering ataupun trap yang bertujuan untuk mencegah longsor. Tanaman pada dusujn 1 didominasi oleh padi, palawija, dan jagung manis. Cara penanaman yang dilakukan oleh masyarakat setempat dengan cara sejajar lereng. Pada dusun 1 terdapat lahan kritis terhampar luas sekitar 14 hektare yang merupakan bekas bahan tambang galian c (pasir) dan lahan tersebut belum mendapatkan penanganan dari pemerintah desa setempat.

b. Dusun 2 Desa Kutamandiri memiliki kemiringan lereng yang relatif landai, lereng tersebut dimanfaatkan masyarakat setempat untuk menanam tanaman sayur dengan cara penanaman sejajar lereng. Masyarakat Dusun 2 Desa Kutamandiri mampu memanfaatkan 
lahan kosong dengan baik hal tersebut dibuktikan dengan sebaran lahan kritis yang sangat sedikit bahkan dapat dikatakan tidak ada.

c. Dusun 3 memiliki kemiringan lereng yang tergolong sedang. Untuk lahan pertaniannya mayoritan ditanami tanaman padai dan ubi jalar lalu sebagian kecil ditanami tanaman cengkeh dengan cara penanaman yang sejajar. Untuk sebaran lahan kritis terbilang masih sedikit dengan cara penanganannya yaitu dengan terasering sehingga kecil kemungkinan terjadiya erosi.

d. Lahan kritis di dusun 4 (Lebakmaja Kaler) memiliki kemiringan lereng yang sedang, akan tetapi sudah minim erosi, hal ini dikarenakan masyarakat sudah membangun rabat beton, dan penahan untuk mencegah tanah longsor. Selain itu, untuk tanaman di dusun ini masih banyak dijumpai tanaman keras (seperti nangka dan mangga). Sedangakan, tanaman sayursayuran terdapat di lahan pertanian. Tanaman ditanam dengan cara searah lereng. Untuk lahan kritis di dusun ini hanya ada sedikit, akan tetapi tersebar di beberapa tempat.

Untuk mengatasi permasalahan lahan kritis dan untuk pengendalian erosi, ada beberapa solusi yang dapat dilakukan atau diterapkan, yaitu: Pembangunan tanggul penahan tanah untuk menangani longsor. Lokasi yang dipilih untuk pembangunan tanggul penahan tanah harus tepat dan memiliki manfaat untuk pencegahan bahaya longsor, banjir atau erosi. Serta dalam proses pembangunannya memanfaatkan potensi sumber daya yang ada di desa tersebut.

\section{Bidang Konservasi Air}

Konservasi air pada prinsipnya adalah penggunaan air yang jatuh ke tanah untuk pertanian seefisien mungkin dan pengaturan waktu aliran air dengan cara meresapkan air ke dalam tanah agar pada musim hujan tidak terjadi banjir dan pada musim kemarau air untuk kebutuhan hidup masih tersedia (Ardiansyah, 2018).

Dalam kegiatan perencanaan partisipatif dalam Program Citarum Harum melalui FGD di Desa Kutamandiri dipaparkan hasil survey dan pemetaan masalah terkait konservasi air sebagai berikut:

a. Pada dusun 1 kualitas air merupakan air yang jernih dan tidak berbau sehingga dapat dimanfaatkan oleh masyarakat setempat dengan baik. Pada dusun 1 terdapat sungai cikeruh yang mengalir terus menerus dengan debit air yang kecil. Masyarakat setempat memanfaatkan air bersih dari sumur gali, penampungan air, dan mata air. Hanya saja pada sumur gali pemanfaatannya sudah berkurang, diakibatkan oleh padatnya pemukiman penduduk sehingga kualitasnya sudah kurang karena letak sumur gali berdekatan dengan septic tank. Oleh karena itu, pihak desa telah membuat sumur arteri yang dipompa airnya 
untuk ditampung disebuah wadah dan dialirkan kerumah-rumah warga disekitar dusun 1 . Selain itu, pada dusun 1 terdapat mata air yang digunakan warga secara bersama-sama dengan langsung mendatangi tempatnya.

b. Kualitas air di Dusun 2 Desa Kutamandiri terpantau jernih \& tidak berbau, pada musim penghujan masyarakat mendapatkan air yang berlimpah, hal ini sangat berkebalikan pada musim kemarau, masyarakat sangat kesulitan untuk mendapatkan air. Untuk mencegah kesulitan air saat musim kemarau, banyak warga yang berinisiatif untuk membuat bor pribadi di rumah masing-masing, tetapi untuk membuat sumur pribadi di rumah membutuhkan biaya yang cukup mahal kurang lebih Rp 17.000.000 untuk sekali pembuatannya. Tetapi hal ini pun tidak bisa menjamin pemilik sumur mimiliki persediaan air yang melimpah saat musim kemarau, sehingga banyak masyarakat yang memutuskan untuk mengambil air di sumber mata air yang tersedia RW 5, RW 6 dan RW 7.

c. Dusun 3 desa kutamandiri memiliki kualitas air yang jernih dan tidak berbau tetapi ketika musim kemarau tiba dusun ini mengalami kesulitan air dan air yang menjadi sedikit keruh. Sumber air pada dusun 3 berasal dari sumur gali, penampung air warga, dan mata air. Untuk mengatasi kekeringan yang sedang dialami oleh dusun 3 sebagian warga ada yang memasang sumur bor dan mereka saling membagi satu sama lain.

d. Kualitas air di dusun ini terbilang cukup kotor namun tidak berbau, air tersebut masih sering digunakan untuk keperluan mencuci dan mandi masyarakat. Selai itu ketersediaan air di tiap rumah cenderung sedikit, sehingga masyarakat menggunakan sumur galian sebagai alternative sumber air bersih. Sumur galian yang ada di dusun ini hanya terdapat di satu RW 11 dan telah mampu di distribusikan untuk 50 kepala keluarga dari total 200 kepala keluarga di dusun tersebut. Sumur galian ini dibangun oleh masyarakat melalui swadaya dan donasi dari pihak-pihak yang memiliki kepedulian lebih terhadap permasalahan air di dusun ini. Sumur galian ini dibangun pada bagian bawah pemukiman dusun,menggunakan pompa untuk dialirkan ke penampungan yang terdapat diatas pemukiman. Penampungan terdiri dari 3 toren yang masing-masing berkapasitas 23.000 Liter.

Selain dari masyarakat yang peduli, sumur galian juga dikelola oleh karang taruna dimana karang taruna tersebut menetapkan iuran $50.000 \mathrm{KK} /$ Bulan. Aka tetapi sistem dari sumur galian ini belum terstruktur dengan baik. Hal ini dikarenakan dalam pengelolaannyamasih belum memiliki sumber listrik mandiri, dan masih di bebankan pada warga sekitar. 
Untuk mengatasi permasalahan lahan kritis dan untuk pengendalian erosi, ada beberapa solusi yang dapat dilakukan atau diterapkan, yaitu:

a. Pembuatan sumur bor dibarengi sumur resapan

- Sumur bor berjarak 10-15 meter dari septic tank

- Sumur resapan harus berada pada lahan yang datar

- Sumur resapan harus berjarak minimal 1 meter dari fondasi bangunan

- Struktur tanah dalam pembuatan sumur resapan harus mempunyai permeabilitas yang baik

b. Penyediaan pompa dan pipa untuk saluran pengadaan penyaluran air ke rumah warga serta pembuatan penampungan air sehingga warga dapat lebih mudah mengakses air bersih untuk kebutuhan hidupnya sehari-hari.

\section{Bidang Sanitasi Lingkungan}

Sanitasi lingkungan adalah status kesehatan suatu lingkungan yang mencakup perumahan, pembuangan kotoran, penyediaan air bersih dan sebagainya (Notoadmojo, 2003). Sanitasi lingkungan dapat pula diartikan sebagai kegiatan yang ditujukan untuk meningkatkan dan mempertahankan standar kondisi lingkungan yang mendasar yang mempengaruhi kesejahteraan manusia. Kondisi tersebut mencakup:

(1) pasokan air yang bersih dan aman;

(2) pembuangan limbah dari hewan, manusia dan industri

(3) perlindungan makanan dari kontaminasi biologis dan kimia;

(4) udara yang bersih dan aman

(5) rumah yang bersih dan aman.

Dalam kegiatan perencanaan partisipatif dalam Program Citarum Harum melalui FGD di Desa Kutamandiri dipaparkan hasil survey dan pemetaan masalah terkait sanitasi lingkungan sebagai berikut:

a. Pada dusun 1 sudah tersedia saluran bersih yang baik karena terdapat kamar mandi dan septic tank disetiap rumah dan mck umum untuk beberapa anggota keluarga. Selain itu, perilaku masyarakat dalam BAB sudah baik.

b. Dusun 2 Desa Kutamandiri terpantau memiliki saluran air yang bersih, hal ini akibat perilaku penduduk masyarakat yang sudah sadar akan pentingnya kebersihan, menurut Ketua RW 05 Dusun 2 Desa Kutamandiri 90\% warganya sudah memiliki septic tank dan kamar mandi di rumah. Dusun 2 Desa Kutamandiri sayangnya belum memiliki TPS dan TPA, sehingga sampah rumah tangga dibakar oleh masing-masing rumah tangga. 
c. Setiap rumah di dusun 3 sudah memiliki toilet pribadi, septic tenk, dan memiliki MCK umum yang berada di RW 13.

d. Ketersediaan saluran bersih untuk setiap rumah memanfaatkan saluran air bersih dari PDAM dan sumur pribadi. Selain itu, sebagian masyarakat juga memiliki septic tank pribadi, dan sebagian lainnya menggunakan septic tank komunal. Dimana septic tank komunal ini memiliki kesekertariatan, akan tetapi pengelolaannya sudah tidak aktif, sehingga tanggung jawab pengelolaan diserahkan kepada masing-masing pengguna septic tank. Selain itu, MCK umum juga tersedia dan menjadi alternative saat terjadinya musim kemarau. Dengan tersediaannya MCK pada setiap rumah, dapat disimpulkan bahwa perilaku BAB masyarakat telah sesuai dengan semestinya.

Prioritas penanggulangan permasalahan sanitasi lingkungan di Desa Kutamandiri dapat direncanakan secara strategis berjangka pendek, menengah, dan panjang.

1. Jangka Pendek

Untuk rencana solusi jangka pendek yang dapat dilakukan adalah pembentukan hal-hal fundamental yaitu kesadaran masyarakat guna menumbuhkan motivasi. Kesadaran masyarakat ini dapat ditumbuhkan dengan ditingkatkannya sosialiasi-sosialisasi kepada masyarakat mengenai pentingnya sanitasi dalam kehidupan yang diiringi dengan tindak lanjut penanganan yang disertai pengembangan infrastruktur.

\section{Jangka Menengah}

Untuk solusi jangka menengah adalah dihasilkannya warga aktif, pembentukan kelembagaan serta peraturan sebagai faktor pendukung. Pembentukan lembaga dilakukan secara partisipatif. Pertemuan pembentukan lembaga, mungkin dilakukan dalam serangkaian pertemuan, sehingga diperlukan notulensi/berita acara dari setiap pertemuan agar tidak diulang pada pertemuan berikutnya. Pembentukan kelembagaan harus dilengkapi dengan struktur kepengurusan, anggaran dasar dan anggaran rumah tangga, surat keputusan kepala desa untuk kepengurusan, standar operasi prosedur pengelolaan IPAL komunal, serta sistem pembayaran dan pembukuan. Peraturan atau regulasi yang dapat dibuat adalah berupa Perdes atau peraturan desa yang mengatur tentang sanitasi lingkungan di Desa Kutamandiri.

\section{Jangka Panjang}

Untuk solusi jangka panjang yang dapat dilakukan adalah dengan dibentuknya sistem Septic Tank yang sesuai dengan ketentuan dan disesuaikan dengan kondisi Desa Kutamandiri agar masyarakat terhindari dari berbagai macam penyakit.

\section{Bidang Pengelolaan Sampah dan Limbah Pertanian}


Pengolahan Sampah merupakan bagian dari penanganan sampah dan menurut UU No. 18 Tahun 2008 didefinisikan sebagai proses perubahan bentuk sampah dengan mengubah karakteristik, komposisi, dan jumlah sampah. Pengolahan sampah merupakan kegiatan yang dimaksud untuk mengurangi jumlah sampah, disamping memanfaatkan nilai yang masih terkandung dalam sampah itu sendiri (bahan daur ulang, produk lain dan energi). Pengolahan sampah dapat dilakukan berupa : pengomposan, recycling/daur ulang, pembakaran (insinerasi), dan lain-lain. ). Pengelolaan sampah juga dilakukan untuk memulihkan sumber daya alam (resources recovery). Pengelolaan sampah bisa melibatkan zat padat, cair, gas, atau radioaktif dengan metode dan keterampilan khusus untuk masing-masing jenis zat.

Dalam kegiatan perencanaan partisipatif dalam Program Citarum Harum melalui FGD di Desa Kutamandiri dipaparkan hasil survey dan pemetaan masalah terkait pengelolaan sampah dan limbah pertanian sebagai berikut:

a. Pada setiap rumah di dusun 1 sudah terdapat tempat sampah yang nantinya akan dibuang di tempat pembuangan sementara. Namun, setelah sampah terkumpul di TPS, sampah tidak dikelola atau didistribusikan ke TPA melainkan langsung membakar sampah di TPS tersebeut, sehingga TPS ini berasa seperti TPA bagi warga setempat.

b. Mayoritas mata pencahariaan Dusun 2 Desa Kutamandiri adalah sebagai petani dan pengerajin gelasan. Hal ini membuat limbah pertanian menumpuk setiap kali panen, tetapi masyarakat memanfaatkan limbah tersebut untuk pakan hewan ternak seperti sapi dan domba.

c. Setiap rumah di dusun 3 memiliki tempat sampah masing masing khususnya di RW 15 sudah tersedia tempat pembuangan sampah sementara. Namun masih belum bisa menampung semua sampah yang berada di dusun 3, berbeda dengan RW 9 yang warganya sudah memiliki kesadaran untuk menggunakan jasa angkut sampah walaupun tidak memiliki TPS karena sebagian wilayah di dusun 3 masih membakar sampah yang mereka hasilkan.

d. Di dusun 4 masyarakat memiliki tempat sampah pada masing-masing rumah, dan belum bengetahui cara pengelolaan sampahnya. Selain itu, di dusun ini tidak memiliki pembuangan sampah sementara, sehingga sampah dari tiap-tiap rumah di kelola secara pribadi dengan cara dibakar.

Pengolahan limbah pertanian di dusun ini tidak diberikan sarana khusus, sehingga limbah akan disimpan dan dibiarkan membusuk untuk menjadi pupuk dan pakan ternak. 
Solusi dari masalah sampah dan limbah pertanian dapat dilakukan dengan berjalannya pemilahan sampah yang merupakan kegiatan penting dalam penanganan dan pewadahan sampah di lokasi sumbernya. Pemilahan sampah dapat diawali dari rumah-rumah dengan fokus terhadap sampah organik dan sampah anorganik. Pemilahan sampah yang baik dan tepat akan memperlancar proses daur ulang.

Pengelolaan sampah yang baik adalah pengelolaan sampah yang berbasis 3R yaitu reduce, reuse, dan recycle. Membangun Bank Sampah merupakan upaya untuk mengubah perilaku masyarakat dalam pengelolaan sampah berbasis 3R dan berbasis ekonomi masyarakat. Konsep Bank Sampah ini merupakan konsep menabung, dimana masyarakat atau nasabah bank menabung dalam bentuk sampah yang sudah dikelompokkan. Sistem operasi dari bank sampah itu sendiri yaitu seperti berikut:

a. Sampah yang disetorkan ke bank sampah dibedakan atas beberapa jenis, seperti sampah organik dan sampah anorganik

b. Sampah rumah tangga digunakan untuk kesuburan tanah yang diterapkan di rumahnya masing-masing.

c. Tiap nasabah memiliki kantong berukuran besar yang tersimpan di bank untuk menyimpan seluruh sampah yang mereka tabung.

Dengan berjalannya operasional bank sampah, warga atau masyarakat sekitar bisa membantu pemerintah untuk membersihkan lingkungan sekitar sekaligus bisa menabung untuk masa depan. Peran masyarakat disini sangat dibutuhkan sekali, masyarakat dapat berperan dengan meningkatkan kesadaran dan kepedulian dalam menjaga kebersihan rumah dan lingkungannya, serta mengurangi jumlah timbulan sampah sejak dari sumber dengan melakukan pengurangan konsumsi barang kemasan, melakukan pemilahan sampah, dan pemakaian kembali atau isi ulang.

\section{Bidang Mitigasi Bencana}

Mitigasi bencana adalah serangkaian upaya untuk mengurangi risiko bencana, baik melalui pembangunan fisik maupun penyadaran dan peningkatan kemampuan menghadapi ancaman bencana (Pasal 1 ayat 6 PP No 21 Tahun 2008 Tentang Penyelenggaraan Penanggulangan Bencana).

Bencana adalah peristiwa atau rangkaian peristiwa yang mengancam dan mengganggu kehidupan dan penghidupan masyarakat yang disebabkan, baik oleh faktor alam dan/atau faktor non alam maupun faktor manusia sehingga mengakibatkan timbulnya korban jiwa manusia, kerusakan lingkungan, kerugian harta benda, dan dampak psikologis. 
Dalam kegiatan perencanaan partisipatif dalam Program Citarum Harum melalui FGD di Desa Kutamandiri dipaparkan hasil survey dan pemetaan masalah terkait mitigasi bencana sebagai berikut:

a. Mitigasi bencana pada dusun 1 sudah baik karena jarang terjadi bencana seperti longsor, banjir, dan gempa. Jikapun ada hanya terjadi longsor-longsor kecil yang disebabkan oleh curah hujan yang tinggi. Hal ini menyebabkan fasilitas untuk mitigasi bencana seperti papan informasi bencana, parameter tangguh bencana, dan orang yang berpengetahuan mitigasi bencana sangatlah kurang.

b. Bencana alam di Desa Kutamndiri sangat jarang bahkan dapat dikatakan tidak pernah terjadi, penyuluhan tentang bencana memang sesekali dilaksanakan, tetapi kurang menarik perhatian warga dan masyarakat karena masyarakat merasa tidak perlu.

c. Sosialisasi mengenai pencegahan bencana di dusun 3 masih kurang dikarenakan saran dan prasarana informasi pencegahan bencana masih kurang memadai. Lalu di dusun 3 pun jarang terjadi bencana seperti longsor dan banjir.

d. Potensi longsor pada dusun ini kecil, karena pemukiman masyarakat sudah membangun rabat beton, dan penahan untuk mencegah tanah longsor. Sedangkan di daerah pesawahan berpotensi longsor jika curah hujan tinggi dan akan menimbulkan kerugian materil. Dusun ini memiliki potensi banjir yang muncul sejak dua tahun lalu yang disebabkan adanya alih fungsi lahan sehingga daerah resapan air menjadi berkurang. Banjir juga disebabkan karena kebiasaan masyarakat yang membuang sampah ke selokan. Sedangkan potensi gempa di dusun ini terbilang kecil dikarenakan letak geografisnya.

Melalui survey terasebut dapat dilihat bahwa kesadaran masyarakat dalam pencegahan bencana masih rendah, hal ini dikarenakan tidak tersedianya papan informasi bencana dan parameter tangguh bencana. Selain itu tidak ada masyarakat yang memiliki pengetahuan mengenai mitigasi bencana.

Solusi atau penanggulangan untuk permasalahan bencana longsor adalah dapat dilakukan dengan membuat resapan air, mengadakan reboisasi atau penanaman pohon dengan tanaman keras, serta membuat sengkedang atau terasering pada lahan pertanian.

Mengenai masalah kebakaran, hal itu dapat dicegah dengan mensosialisasi kepada masyarakat mengenai antisipasi atau hal yang sebaiknya dilakukan ketika terjadi kebakaran, lalu masyarakat juga dihimbau untuk tidak membakar sampah sembarangan, mensosialisasi kepada masyarakat untuk mempergunakan instalasi listrik dengan benar dan teratur serta berhati-hati dalam penggunaannya. 
Untuk solusi atau prioritas penanggulangan masalah dampak galian C yang ada di Desa Kutamandiri dapat dilakukan dengan membuat Amdal, membuat sumur resapan, membuat irigasi atau perairan yang baik, memperluas selokan baik secara tersier maupun sekunder, serta penanaman pohon yang berguna juga untuk kebaikan lingkungan.

Untuk masalah banjir dari sungai yang berdampak ke sawah-sawah di desa, perlu dilakukannya pembersihan dan perbaikan drainase yang optimal, membuat bak penampungan sampah yang memadai yang dapat menampung sampah-sampah agar tidak mencemari lingkungan sehingga mengurangi resiko banjir, serta perlu juga adanya penyuluhan atau pendekatan edukatif mengenai banjir kepada masyarakat desa.

Mengenai permasalahan kekeringan yang berdampak pada kesulitan tersedianya air, hal yang dapat dijadikan solusi di antaranya adalah membuat sumur bor atau sumur artesis, lalu membuat sarana penyaluran air dari sungai ke sawah, pengelolaan sumber mata air agar bisa bermanfaat untuk masyarakat, serta membuat sumur resapan.

\section{SIMPULAN}

Berdasarkan hasil dan pembahasan tentang perencanaan partisipatif dalam Program Citarum Harum melalui FGD yang berbasis “active citizens” di Desa Kutamandiri Kecamatan Tanjungsari Kabupaten Sumedang, maka diperoleh usulan-usulan program dan kegiatan sebagai upaya untuk mengantisipasi dan mengatasi permasalahan di bidang penanganan lahan kritis dan pengendalian erosi, bidang konservasi air, bidang sanitasi lingkungan, bidang pengelolaan sampah dan limbah pertanian, serta bidang mitigasi bencana.

Usulan-usulan dalam FGD tersebut tersebut merupakan yang dilakukan dalam mengatasi pemermasalahan dalam Program Citarum Harum, dimana secara garus besar dapat disimpulkan sebagai solusi yang dapat dilakukan dalam lingkup jangka pendek, jangka menengah dan jangka panjang. Solusi tersebut merupakan rencana keberlanjutan dari hasil FGD yang dilakukan Tim KKN UNPAD pada program KKN Citarum Harum di Desa Kutamandiri.

Solusi jangka pendek merupakan solusi terhadap permasalahan yang terkait program Citarum Harum dapat dilakukan saat ini, dengan memberdayakan sumber daya yang ada (warga) dan merupakan kegiatan rutin yang bisa dan selalu dilakukan warga dalam kehidupan sehari-hari, seperti membiasakan pola hidup sehat, buang sampah pada tempatnya, di setiap rumah ada tempat sampah, di setiap rumah menanam warung hidup dan apotek hidup (minimal dalam pot), tidak boros menggunakan air di saat musim kemarau, mengatusipasi 
timbulnya bencana kebakaran (karena kelalaian warga), gotong royong atau kerja bakti membersihkan lingkungan sekitar warga, melakukan olahraga masal minimal 1 minggu 1 kali, dan sebagainya.

Solusi jangka menengah dilakukan dengan adanya kemauan dan kekompakan antara warga desa dengan lembag-lembaga yang ada di desa, baik lembaga pemerinathan maupun lembaga kemasyarakatan dalam mengantisipasi permasalahan-permasalahan dalam bidangbidang yang terkait dengan program Citarum Harum di Desa Kutamandiri. Kegiatan yang dilakukan antara lain, menanam pohon keras untuk mencegah terjadinya longsor di lahan yang dekat dengan aliran sungai; adanya program reboisasi yang diakukan warga desa dan didukung oleh pemerintah berupa pemberian bibit-bibit tanaman yang cocok dengan kondisi tanah di wilayah Desa Kutamandiri; membuat sumur bor yang dapat digunakan secara masal oleh warga, yang dapat dimanfaatkan saat musim kemarau, namun harus memperhatikan syarat kesehatan untuk mendapatkan kualitas air yang sehat, bersih dan tidak tercermar limbah; disediakan tempat sampah di tempat-tempat umum (fasilitas umum), adanya kegiatan sosialisasi dan pelatihan pemilahan sampah bagi warga dan siswa sekolah di wilayah Desa Kutamandiri untuk dapat digunakan dan diolah menjadi pupuk kompos atau pun menjadi barang-barang yang dapat digunakan kembali; membentuk pengelola sampah dari warga yang bersifat swadaya atau dibayar oleh warga, yang mengangkut sampah dari setiap rumah warga ke tempat pembuangan sementara, dan selanjutnya diangkut ke tempat pembuangan sampah akhir; dibangun septic tank komunal secara bertahap dengan memperhatikan syarat-syarat kesehatan; serta adanya sosialisasi dan pelatihan tentang mitigasi bencana bagi warga, agar siap dan siaga terhadap terjadinya bencana seperti longsor, banjir dan kebakaran.

Solusi jangka panjang dilakukan dengan memperhatikan kebijakan pemerintah pusat, pemerintah provinsi dan pemerintah kabupaten dalam impelementasi program citarum khusunya, dan implementasi kebijakan terkait bidang pertanian (penangann lahan kritis), bidang pekarjaan umum dan pengairan (konservasi air), bidang kesehatan (sanitasi lingkungan dan pengelolaan sampah), bidang pelayanan publik dan pemberdayaan masyarakat (pengelolaan sampah), bidang pertahanan dan keamanan dan program BPBD (mitigasi bencana), yang dalam implementasinya membutuhkan dukungan dana, sumber daya manusia, fasilitas yang harus didukung oleh berbagai pihak (stakeholders). Kegiatan jangka panjang terkait program Citarum Harum, antara lain: Dibangunnya TPS atau TPA serta tempat pengelolaan sampah yang dana pembangunannya didukung dan difasilitasi oleh pemerintah terkait maupun oleh pihak-pihak lainnya (stakeholders), sehingga program bank 
sampah yang sudah dirintis melalui program ecovillage dapat diteruskan dan dapat mengatasi permasalahan sampah di Desa Kutamandiri. Dalam bidang konservasi air, dibangun penampungan sumber mata air (ada 8 sumber mata air) dan dibuat pipa yang dapat menyalurkan air tersebut ke pemukiman warga. Hal tersebut mebutuhkan bantuan dan dukungan dana dari pemerintahan terkait dalam mewujudkannya atau adanya pihak-pihak lain di luar pemerintah yang dapat membantu pembangunan penampungan air dan pipa-pipa yang menyalurkannya.

\section{DAFTAR PUSTAKA}

Abe, Alexander. (2005). Perencanaan Daerah Partisipatif. Yogyakarta: Pustaka Jogja Mandiri.

Adisasmita, Raharjo. (2006). Pembangunan Pedesaan Dan Perkotaan. Yogyakarta: Graha Ilmu.

Ardiansyah, Tomi. (2018). Konservasi Tanah dan Air. https://foresteract.com/konservasitanah-dan-air/

Conyers, Diana. (1991). Perencanaan Sosial di Dunia Ketiga: Suatu Pengantar. Ed 2. (Penerjemah: Susetiawan). Yogyakarta: Gajah Mada University Press.

Direktorat Pendidikan dan Kemahasiswaan UNPAD. (2019). Proposal KKN Citarum Harum 2019. Jatinangor: UNPAD.

Jones, Charles O. (1996). An Introduction to the Study of Public Policy. Brooks: Cole Publishing Company.

Laily, Elida Imro’atin Nur. (2015). Partisipasi Masyarakat dalam Perencanaan Pembangunan Partisipatif. Jurnal Kebijakan dan Manajemen Publik Vol. 3 No. 2, Mei-Agustus 2015. 186-190

Notoatmojo S. (1993). Ilmu Kesehatan Masyarakat Prinsip-Prinsip Dasar. Jakarta: Penerbit Rineka Cipta.

Poerwowidodo. (1990). Gatra Tanah dalam Pembangunan Hutan Tanaman di Indonesia. Rajawali Press. Bogor.

Putri, Dian Anggreini dkk. (2014). Efektivitas Program Penataan Lingkungan Permukiman Berbasis Komunitas Di Kelurahan Titiwungen Utara Kecamatan Sario Kota Manado. https://media.neliti.com/media/publications/73525-ID-efektivitas-programpenataan-lingkungan.pdf. Hal 1-8. 
Republik Indonesia. (2008). UU No. 18 Tahun 2008 tentang Pengelolaan Sampah.

Republik Indonesia. (2008). PP No 21 Tahun 2008 tentang Penyelenggaraan Penanggulangan Bencana.

Sili, Maria A. Radji. (2014). Proses Perencanaan Partisipatif dalam Rehabilitasi dan Rekonstruksi Permukiman Pasca Bencana Merapi 2010.

http://etd.repository.ugm.ac.id/ 